\title{
Counterproductive contributions to African Epidemiology
}

\author{
Helen Lauer ${ }^{1 \star}$ and Joan Shenton ${ }^{2}$ \\ 'Professor, University of Dar es Salaam, Tanzania \\ ${ }^{2}$ Director, Meditel Productions, UK
}

\section{Article Info \\ *Corresponding author: \\ Helen Lauer \\ Professor \\ University of Dar es Salaam \\ Dar es Salaam \\ Tanzania \\ E-mail: helenlauer@yahoo.com}

Received: November 14, 2017 Accepted: November 17, 2017

Published: November 24, 2017

Citation: Lauer H, Shenton J. Counterproductive contributions to African Epidemiology. Madridge J Immunol. 2017; 1(1): 28-39. doi: $10.18689 / \mathrm{mjim}-1000108$

Copyright: ( $\odot 2017$ The Author(s). This work is licensed under a Creative Commons Attribution 4.0 International License, which permits unrestricted use, distribution, and reproduction in any medium, provided the original work is properly cited.

Published by Madridge Publishers

\begin{abstract}
Throughout this retrospective, our purpose is to illuminate an evident knowledge handicap, cutting across the diagnostic procedures, reportage and mathematical modelling of chronic illness affecting African public health demographics, which we trace to three epistemic injustices (methodological, documental, and professional) in the way medical research in Africa is managed and monitored by foreigners. We propose that the mutual reinforcement of these three different kinds of epistemic transgression underlies the chronic failure of immunologists and public health practitioners to subdue the inflated rates of morbidity and short life expectancy persistent throughout Africa. Substandard data collection and implausible infection modelling count as injustices because they are traceable to a routine disregard for best scientific practice at the upper echelons of global health authority, which is betrayed by an inordinately high tolerance for diagnostic error concerning populations that are disproportionately disadvantaged as a norm, who are therefore regarded as low credibility risks in the global production and dissemination of medical knowledge. To ground these claims, we rely upon direct observations and anecdotal evidence culled from two different sorts of public health crisis in Africa which have received widespread publicity: (i) the eighteen-month-long international emergency response to a West Africa Ebola outbreak in 2014-2015, and (ii) attempts over the last quarter century to quell an extensively researched African HIV/AIDS pandemic.
\end{abstract}

Keywords: West African 2014 Ebola crisis; HIV/AIDS in Africa; Methodological injustice; Documental injustice; Professional injustice; suppression of evidence; Location-based disregard; Marginalizing scientific peers.

\section{Identifying shortfalls in medical theory and practice as types of global injustice}

A disproportionately high level of error and substandard analysis is tolerated by international experts when Africans' chronic contagions and avoidable fatalities are the subject of diagnostic measures and descriptive reportage. In consequence, misimpressions and popular stereotypes about African public health proliferate in the global arena through public media channels as well as specialist scientific journals. We regard the high frequency of error tolerated in diagnostic methods and data collection as methodological injustice; and we frame as documental injustice the resulting proliferation of falsehoods that recur in published research, such as Fact Sheets which reiterate for the general public grossly oversimplified etiologies and exceptionalist narratives about African pathogenicity. The concerns raised here reflect fundamental principles of best scientific practice, [1] which prevail independently of disputes about 
the relative efficacy of different methodologies in determining infectious causation [2]. Further, global ignorance about Africa's chronic contagions is sustained by a tendency to disregard or neglect the views of scientific peers based upon the location of their practice or institutional affiliation in low income, resource poor countries. We label this third type of epistemic transgression professional injustice because it prevents the detection and correction of gross error by those experts who are best placed to upgrade the accuracy and quality of global discourse about African morbidity and mortality. This in turn inhibits the quality of treatment that patients receive.

These three types of epistemic transgressionmethodological, documental, and professional-register as injustices because they are responsible for practices and policies which exacerbate Africans' chronic ill health and short life expectancy. We argue that the mutual reinforcement of these different kinds of epistemic injustice underlies the chronic failure of immunologists and public health practitioners to subdue the disproportionately high rates of morbidity and high fatality in East, West, South and Central Africa, despite the billions of dollars invested to alleviate imbalances in the distribution of the global disease burden. Since the 1980s, trends in epidemic control strategy and health care delivery programming in Africa have been dominated by the way that chronic illnesses in sub Saharan regions are reported and understood internationally. To demonstrate this, we provide evidence collated over the last three decades from direct observations, propagated Fact Sheets, daily news broadcasts, and interviews with the principals involved first hand in: (i) the eighteen-month international emergency response to the West Africa Ebola outbreak in 2014-2015, and (ii) the last quarter century of an extensively researched and publicized African HIV/AIDS pandemic. These two officially declared viral contagions were substantially different in their officially narrated time frames, etiologies, pathogeneses, and the global alarm that was generated about them. Nonetheless striking parallels emerge in the kinds of epistemic transgression committed in diagnosis and data collection, the doomsday prognoses promulgated, and the treatment paradigms adopted by the international community's interventions to arrest the West African Ebola 'outbreak' and the HIV/AIDS 'pandemic', respectively. To demonstrate these parallels, the next two sections will address two glaring aspects of what we regard as methodological injustice: we will focus in section 2 on the working definitions used to characterize AIDS throughout Africa, and Ebola in West Africa. In section 3 we examine the diagnostic methods used to track these two contagious factors purportedly responsible for the disproportionately high mortality rates recorded in Africa since the early 1980s. Section 4 will focus on examples of documental injustice, i.e. the authorized promulgation of error and misinformation about African pathogenicity and short life expectancy which have become normalised over the last thirty-five years. In section 5 we highlight some examples of the professional injustice which obstructs local authoritative experts from taking the lead in identifying factors responsible for weakened or broken immunity in their regions, and in determining what to do about it.

\section{Deceptive definitions}

'AIDS' around the world carries various authorized connotations which get conflated without notice. This yields confusion and error at various levels of research and review, product development, treatment choice, health care delivery, political lobbying, civic advocacy and health education. In particular, since the mid-1980s there has been no uniformity in the operational definition of 'AIDS' on the African continent [3]. Long before 1983 when 'HIV' entered common parlance through press releases generating initially from the United States [4-7], the symptoms of an immune-dysfunctional syndrome that features wasting, anaemia and diarrhoea emerging in adulthood had been presented frequently enough in Africa to attract the nick-name 'Slims' [8].

Chronic illness readily associated elsewhere in the world with malnutrition, substandard living conditions and protracted wartime conditions, get relabelled and identified in the global arena as exceptional to the unique cultural and material disadvantages of life in Africa [9-11]. In war torn countries where deeply impoverished populations have little or no access to medicines or conventional health care, it is not unusual to encounter adults presenting with a rapid decline of ten percent or more in body weight and persistent diarrhoea over a thirty to sixty day period, fever and anaemia, swollen lymph glands at two or more sites with no discernible direct cause [12], [13]. For instance as a matter of historical fact, the background of Uganda's 'full blown AIDS crisis' [14] prior to the country's brief health renaissance of the 1980s, cannot realistically be isolated from the fiscal constraints imposed through International Monetary Fund's (IMF) supervised borrowing, nor from the chaotic vista of violence prevailing through the countryside since 1962, under state-sponsored turmoil and massacres [15-17]. Systemic immunity in Ghana was less violently but no less viciously undermined by the effects of the IMF's structural adjustment programming coupled with famine in 1983, which led the Ghana Government to launch its own Program of Action to Mitigate the Social Costs of Adjustment (PAMSCAD) [18]. Simultaneously, in the Republic of South Africa, the intergenerational cumulative effects of apartheid crippled the immunity of the majority of its population in ways that were never recognised, until 1994 when the government first began to record in its official census the births or deaths of people who had formerly been classified as 'Black', 'Indian' or 'Coloured'. 1994 marked the first time racial groups other than Whites were allowed to enter government-run hospitals or clinics [19], [20].

In the 1980s it became acutely important to research chronic immuno-suppression in regions where laboratory procedures are frustrated by unreliable or absent electricity supply and road networks. So, in 1985 the United Nations' World Health Organization (UN WHO), in collaboration with the United States' Center for Diseases Control (US CDC), 
convened a conference at Bangui in Central African Republic where a clinical definition of AIDS was crafted specifically for use in Africa [21]: any three or four of the five symptoms (rapid weight loss, anemia, fever, diarrhea, swollen glands, for one month) without reference to any HIV-antibody (or other) test result, and without reference to any specific disease [22]. Thus the official definition of AIDS provided by the CDC is different in G-7 countries from the way it has authorized AIDS to be defined and diagnosed around Africa since 1985. In the US, UK and elsewhere, an AIDS diagnosis may be asymptomatic but it does require two distinct corroborating HIV positive test results.

In consequence there is no uniformity in the diagnosis of AIDS for the African continent. Different countries' health ministries depend upon one or more of these defining symptoms, some with and others without supplementary antibody test results. For instance, it is not known exactly when, but sometime in the 1990s the Ghana Health Service introduced the Enzyme Linked Immunosorbent Assay (ELISA) 'rapid test'; and the standard Western Blot (WB) was sometimes used to back it up, according to Dr.Addo, DirectorGeneral of the Ghana AIDS Commission at the time. But this requirement was not typical of the continent overall: in 1991, Tanzania and Uganda recorded AIDS cases without reference to tests at all. Tests have neither always nor everywhere been required by the WHO or UNAIDS in Geneva collating their data for annual statistical reports about Africa. Many Africans who qualify for an AIDS diagnosis-perhaps as many as seventy percent-turn out to be negative when tested for HIV according to the Western Blot [19] [77]. In sum, the WHO 1985 Bangui clinical definition of AIDS was intended to overcome the problem of studying chronic immunosuppression. Instead it became a catch-all term that "simply re-labels symptoms of poverty as AIDS" [23].

In any case, the acronym 'AIDS' refers to a syndrome, which is not a disease [10], [46], [19], [75]. Yet 'AIDS', 'HIV/ AIDS' and 'the HIV disease' are used interchangeably. African virologist James Brandful has remarked that the most troubling misconception he observes in the public domain is the belief that there is only one microbial form or type of 'HIV' which is singly responsible for causing 'AIDS' uniformly everywhere [24], [25]. The reality as measured throughout Africa does not sustain this widespread assumption. Instead, "the current genomic profile of the HIV is not only widely variant worldwide, but in some regions pure line strains originally observed are now co-existing with recombinant strains which are getting more complex, for example in Ghana" [24], [25], [26]. According to the orthodoxy, recombinants of HIV are unstable and evolving; so distinctive variants of the entities standardly identified as HIV are mutating throughout Africa differently from the variants which dominate in the countries where HIV/AIDS is observed to be subsiding.

The non-specificity of the official definition of AIDS plays a central role in the social conditioning that has instilled mainstream beliefs about the urgency of disseminating anti- retrovirals exclusively, while searching for a vaccine to undermine an ostensibly essential, clearly defined and scientifically established link between one pathogenic entity called 'HIV' and AIDS as it occurs throughout the world. But this research and development agenda for Africa is not substantiated by the available evidence [27], [28].

The vagaries of HIV/AIDS definitions are not the only examples of obfuscation and sensationalism in the etiological lexicon applied to Africa. The use of 'Ebola' in reference to West Africa mortality rates measured over an eighteen-month period from 2014 through 2015 has been comparably question begging. The label 'Ebola' was originally adopted from the name of a river in Zaire and allocated by those claiming its discovery as a new type of filovirus in 1977 [29], [30], [31]. But several weaknesses of the research design described in these "preliminary communications" [29, p. 570] do not stand up to critical scrutiny [32]. Identification of Ebola as pathogenic in humans was based upon only a single individual whose liver tissue samples were poorly handled according to the authors of the report [29, p. 571]. The electroscopic photographs ostensibly exhibiting the filovirus are of such low resolution that it is far from conclusive whether a viral agent was present in the illustrated sample. Further, if the entity was a virus, the quantity of this material displayed in the electroscopic photograph was grossly insufficient to warrant concluding its pathogenicity in this case. While no one disputes the fact that Ebola viruses have been well established as morbific in green monkeys, apes, pigs, bats, guinea pigs [30], and mice [31], this kind of filovirus has not yet been reported as isolated or purified in human blood or tissue. In arable regions of Africa, it would be important to rule out environmental factors: one familiar source of acute toxic poisoning leading to hemorrhagic fatalities is the accidental ingestion of chemical pesticides. Another known vocational hazard in African regions that support mineral mining is exposure to heavy metals and poisonous effluents from metallurgical processing that pollute the atmosphere and drinking water. As in the findings mentioned above [29-31], published citings of Ebola in studies of outbreaks in Uganda, the Democratic Republic of Congo, Sudan and Zaire have failed to rule out other possible causes of the observed hemorrhagic fever incidents [33].

Furthermore, subsequent studies in the Central African Republic, Chad, Cameroon, the Congo, Equatorial Guinea and Gabon have discovered viral reactive antibodies in significantly high percentages of perfectly healthy populations [34-40]. As is the case with many antibodies, these studies indicate that the filoviral material is carried and circulates in general populations without any basis for inferring from a correlation to a causal relation with symptoms of Ebola Hemorrhagic Fever. Hence defining 'Ebola' as causally responsible for human fatalities associated with hemorrhagic fever is not yet evidence-based. Similar points have been made about the causal association connoted by semantic juxtaposition of the acronyms 'HIV' and 'AIDS' [41-49].

Most perplexingly, Ebola's clinical definition has changed markedly from Ebola Haemorrhagic Fever (EHF) in the 1970s 
and 1990s, to Ebola Virus Disease (EVD) as of 2014. It is not clear what the relation between the referent of 'EHF' and that of the term 'EVD' is supposed to be. In a sample of forty-four hospitalised patients treated as Ebola cases in Sierra Leone in 2014, bleeding was recorded as symptomatic for only one of the patients [51]. Currently the standard definition of a confirmed case EVD requires presentation of the following four symptoms: (i) low grade fever (less than one degree above the upper limit of normal); (ii) severe headache or vomiting, diarrhea and abdominal pain or more traditional symptoms of Ebola; (iii) a positive laboratory test for Ebola; and (iv) the presence of the patient in a declared Ebola area or having had contact with an Ebola patient in the twenty one days prior to presentation [51]. No bleeding is mentioned in the definition of EVD. According to the official public directives as of 2014, every person within or bordering the region of a declared outbreak with a slight fever and a severe headache is a probable case of Ebola, and everyone with a positive antibody test result is a confirmed case of Ebola. The early signs of EVD were widely publicized in a precautionary move from the outset of the emergency, signaling the public to report to a clinic at once with any of the following symptoms: headache, fever, dizziness, cough, nausea, bloodshot eyes, rash, joint pain, muscle or body aches, sore throat, weakness, stomach distress, loss of appetite [52]. Thus by clinical definition in accordance with its early symptoms, Ebola remained indiscernible from malaria, meningitis, pneumonia, tuberculosis and other upper respiratory infections, typhoid, diabetic shock, and gastro-enteritis including cholera. Because of regional co-factor, these latter treatable infections are also fatal in West Africa. To avoid such undermining effects on primary health care delivery, an Ebola diagnosis would never be hazarded in the United States until typhoid, diabetic shock, and malaria had been definitely ruled out. But in West Africa typhoid and malaria are endemic-hence the 'crisis' in fatalities and symptoms of chronic contagion continued anonymously throughout 2014-2015, as it does to a greater or lesser extent to this day, albeit without global notice or alarm.

\section{Dubious diagnostics}

Under the conditions prevailing during the crisis of 2014-2015 in Freetown of Sierra Leone, Monrovia of Liberia, and villages of Guinea, many people suspected of being Ebola victims could not be tested effectively or at all. Even under ideal conditions for administering the Ebola antibody test, its unreliability had already been established in West Africa years before the presence of Ebola was declared a crisis in the region in 2014 [39], [40]. A random country-wide test for Ebola was conducted in 2010 involving more than five thousand subjects throughout Gabon [39]. A significantly high percentage of healthy subjects yielded positive for Ebola, over nineteen percent of these positive test results were in forested areas. None of those who tested positive displayed any symptoms of Ebola infection. This led the authors to conclude that Ebola is not actually pathogenic; in most cases it causes no symptoms, corroborating earlier studies. Control of Ebola detected by this diagnostic would be impossible [39], [40]. Further, the results suggested that there must be a co-factor that turns a virus which is not harmful in some people into one which is fatal for a high percentage of those who contract it. Alternatively, Ebola testing may be unreliable and perhaps nobody who tested positive in the study was infected; perhaps a co-factor, as yet unknown, would be required to account for fatal morbidity. Yet again, given such a high number of false positives, it might be concluded that the observed virus played no role whatsoever in progression to EHF.

The consequences of such a deceptively non-specific antibody test in the midst of a declared killer contagion were predictably devastating for local populations in West Africa throughout the declared emergency intervention responding to the Ebola outbreak [52]. Threat of forced quarantine via ad hoc diagnosis of Ebola based on one's sheer location, prevented people from visiting clinics for appropriate and available treatment they could have otherwise received for typhoid, cholera, TB, diabetes, meningitis, other URIs and G-E illnesses. The early non-specific symptoms of Ebola as defined for the 2014 outbreak were: headache or mild fever, dizzy spells, cough, nausea, bloodshot or sore eyes, rash, or body aches - indiscernible from these other illnesses. One study conducted in Guinea during the declared crisis recorded that outpatient attendance fell dramatically by nearly half (fortytwo percent) compared with pre-crisis years. In 2014 the number of treated malaria cases dropped up to sixty-nine percent, resulting in an estimated 74,000 cases of malaria going untreated in 2014 [53]. Such disruption of ordinary citizens' everyday lives and consequent economic ruin [52], resulting from the usurpation and mismanagement of public health care service structures by foreign agents, albeit temporary, would never be tolerated in any G-8 country without a major political and diplomatic meltdown.

Ebola antibody tests have disenfranchised many thousands of people from their basic entitlement to health: [54] which presupposes effective primary medical care [55]. However it would be wrong to regard the dismissal of rigor and accuracy in diagnosis as exceptional to the West Africa Ebola emergency exercise in global intervention. The precedent for tolerating misdiagnosis as an established groundwork for representing epidemiological demographics of Africa had already been set by thirty five years of surveillance of HIV via antibody tests.

A fundamental criticism of HIV testing was forwarded as early as 2001 by an organic chemist Dr. Rodney Richards [56], [57] who helped design the first generation of Elisa Link Immonosorbent Assay (ELISA) and subsequent test kits at the American Applied Molecular Genetics (AMGEN) and Abbott Laboratories. Richards observed that the major HIV tests (ELISA, Western Blot, branch DNA, p24 antigen, PCR 'viral load') have contributed to confusion about AIDS in Africa because these test kits are designed for screening blood for safety in transfusions. They are accurate as indicators of 
surrogate markers of AIDS, but not for diagnosis of the presence of HIV infection. From the outset they were never approved for diagnosing by the US National Institutes of Health, the US Food and Drug Administration, nor by the test manufacturers themselves, as indicated clearly in the packaging literature published up through 1997:

"EIA testing alone cannot be used to diagnose AIDS, even if the recommended investigation of reactive specimens suggests a high probability that the antibody to HIV-1 is present. At present there is no recognized standard for establishing the presence and absence of HIV-1 antibody in human blood. Therefore sensitivity was computed based on the clinical diagnosis of AIDS and specificity based on random donors" [Abbott Laboratories, Diagnostic Division, 66-8805/R5; January, 1997]

"Do not use this kit as the sole basis of diagnosing HIV-1 infection" [HIV-1 Western Blot Kit, Epitope, Inc.OrganonTeknika Corporation PN201-3039 Revision \#8]

"The Amplicor HIV-1 Monitor test is not intended to be used as a screening test for HIV or as a diagnostic test to confirm the presence of HIV infection." [Roche Diagnostic Systems, Inc., Amplicor HIV-1 Monitor Test Kit. US: 83088. June 1996, 13-06-83088-001].

Indeed, researchers and diagnosticians are quick to correct a popular misconception about the HIV positive test result: a surrogate marker for high risk of AIDS onset is not a definitive sign of the presence of a manifest single disease. It certainly is not a basis for beginning a prescriptive drug regime. And yet nowadays this is almost uniformly how an HIV positive test result is understood and used in Africa [58].

So the question arises whether all subsequent improvements on the original tests are mere elaborations of a flawed protocol. Richards emphasizes that the test kits up through the 1990s were designed to identify AIDS risk groups, to indicate surrogate markers of potential susceptibilities, and for screening blood to ensure safety of blood transfusions. Tests might be able to "indicate an underlying abnormal propensity to develop a number of illnesses, some of which may prove fatal. A positive 'HIV antibody test' is no more than a non-specific marker for this proclivity." According to Richards, "the inappropriate use of antibody tests for the purpose of diagnosing infection with HIV can be traced back to 1987, when the US Centre for Infectious Diseases Control and Prevention declared: 'The presence of antibody indicates current infection' [59], [60]. Yet as Richards and others have observed, this claim is not substantiated by evidence [61-63]. Meanwhile physicians continue to use nonspecific versions of the tests to tell people they are infected, or are at risk of infection with a deadly virus from their sexual partner or in the course of performing medical procedures, and that transmission is a high risk for their children. These claims are sustained contrary to available evidence [64-68]. The reasons for the test restrictions and complications in diagnosis arise chiefly from the non-specificity of the test kits and non-uniformity of their interpretation [56], [57]. Nevertheless decisions to initiate toxic therapy and to prosecute defendants for wilful transmission of HIV have been based on these tests. Subsequently some of these diagnoses, prescriptions, and criminal allegations have been challenged in law courts, proven false and overturned [69].

As many practitioners in Africa have affirmed [70], [71] diverting test kits designed for blood screening into the service of individual diagnosis can be utterly devastating. To depict just one example from early in 1993: a medical investigative journalism team commissioned by UK's Channel 4, interviewed Uganda's leading TB expert, Dr. Martin Okot-Nwang, based at the Old Mulago Regional Referral Hospital of the Makerere College of Health Sciences [72]. He recounted how a group of researchers from an American university had swooped into his wards, taken blood samples from his patients and flown the serum out of the country. The blood was then tested for 'HIV' and the patients that tested antibody positive were moved out of the hospital's TB wards and into AIDS wards, where their TB regime was terminated and they were given powerful antivirals instead. Many of these patients died. Antiretrovirals cannot cure tuberculosis; yet their prescription in Africa is interrupting and pre-empting administration and further research for improving drugs that can. Fifteen years ago, spending on AIDS research already exceeded spending on TB by a factor of 90 to 1 [73], when two million Africans were contracting tuberculosis every year. Since then the problem has worsened with the emergence of multi-drug resistant bacteria [74]. Initially only nonpulmonary tuberculosis was classified as a disease that qualified as AIDS by the US Centers for Disease Control, but pulmonary TB was added to their list in January 1993 [75].

Malaria is another enormous problem in Africa; it remains the most lethal illness for children under five on the continent [76]. In earlier HIV antibody test kits, malaria registered as another false positive test result, along with leprosy, leishmaniasis, and other neglected tropical diseases [3], [70], [77]. Arguably, the known lack of specificity of antibody tests is valuable as a means of increasing the apparent relevance of an HIV positive status which ratifies investment in costly anti-retroviral treatment, now recommended as a prophylaxis against an ever increasing range of diseases relabeled 'opportunistic' infections [6].

\section{Faulty statistics}

Non-specificity of the test results and non-uniformity of their interpretation yields demographics riddled with errors. The CDC proclamation that a positive HIV test indicates the presence of a sexually transmitted contagion was quickly accepted as fact and henceforth formed the foundation of all subsequent diagnoses of HIV infection, including the UNAIDS/WHO annual estimates. These reached forty million global infections and twenty-five million cumulative AIDS deaths in 2001 [78]. As of 2015, thirty-six million people infected with HIV worldwide were claimed by UNAIDS to require treatment, motivating the call for more funding in the search for an HIV vaccine [79]. 
Meanwhile, the population explosion in Africa is a news item in the global media, with projections that by 2050 most of the world's births will be occurring in Africa [80]. Global health authorities declare that the cessation of HIV/AIDSrelated deaths is due to widespread access to anti-retrovirals. But population continued to grow steadily in Africa whilst the alleged spread of the killer virus was at its peak. For Uganda, once hailed as the 'epicenter of a worldwide HIV epidemic' the USAID recounted the World Health Organization's confirmation in 1995 that "by mid-1991 an estimated 1.5 million Ugandans, or about nine percent of the general population and twenty percent of the sexually active population, had HIV infection" [81]. Subsequently, estimates of the number of HIVpositive Ugandans increased even further, to fifteen percent of the total population [82]. Most were expected to die prematurely with disastrous consequences for their families and the country. Nevertheless, long before the advent of antiretroviral access campaigns, the growth rate in Uganda was 3.4 percent, doubling the population in twenty-one years. Similarly, population growth in South Africa has been growing steadily, despite the expectations of HIV epidemiological reports over the last thirty years [83], [84].

Anomalies in epidemiological reportage about HIV/AIDS are by no means exceptional. Consider for example the weekly record keeping in the final quarter of 2014 of Ebola cases and Ebola related deaths by the US CDC and WHO, released to Reuters and Associated Press, as reported by US State Department Deputy Ebola Coordinator and Crisis Operations Manager Anthony Banbury for the BBC World service News Update October 16, 2014 [85].

The very nature and dimension of the Ebola crisis shifted midway through the reportage. In late September 2014, Peter Piot, the Director of the London School of Hygiene and Tropical Medicine, member of the WHO Advisory Group on the Ebola Virus Disease Response and founding head of UNAIDS, claims to have declared a global health emergency to manage a dangerous EBola epidemic in West Africa. Having fund raised eleven million dollars within a few days to roll out a new experimental drug for the effort, Piot explained that the WHO Ethics Committee requires that conditions constitute a 'dangerous emergency' of epidemic proportions to justify proceeding with phase II mass experimental trials involving healthy humans to test a vaccine. By mid-September, already 950 deaths were attributable to Ebola in West Africa since April. But 'epidemic' denotes a rate of infection resulting in 15 out of 100,000 people or $0.015 \%$ over a 15 day period. According to an ECOWAS annual census estimated for 2013, the population of West Africa was 340 million at the time, indicating over a six month period an Ebola infection rate of $0.00028 \%$-nowhere near an epidemic. Shortly after this observation was released in the social media, the term Ebola 'outbreak' entered public discourse and reference to an Ebola 'epidemic' disappeared. General reference to the vast region of West Africa was replaced with steadfast consistency by 'Guinea, Liberia and Sierra Leone'. For the first week in October, 3,769 cases were reported from Liberia
[85]. But even in retrospect neither the CDC nor WHO were prepared to offer a breakdown of how many of these deaths were male, nor how many were children under twelve years, nor how many patients in the same locations over the same period had died of malaria or tuberculosis or diabetic shock, pneumonia, typhoid, toxicity, gastro-enteritis or malnutrition-related diseases.

How many West Africans contracted Ebola depended upon where and how you looked for them. Since the serum test procedures so frequently yielded false results, the main question doctors considered in diagnosis was whether and how recently the patient presenting was in - or had exposure to any one in-Sierra Leone, Guinea or Liberia [86]. In Liberia, as in many African societies, unless there is a forensic imperative, autopsies are 'verbal', as testified by respected elders, priests, funeral organisers, relatives, neighbours, and traditional family heads. So the number of fatalities due to the stigma of Ebola was often determined by the deceased's status in the community. When a patient died before test results were returned, death was recorded as Ebola-related. In October 2014, Sierra Leone's capital witnessed a sharp spike in Ebola cases with the arrival of new surveillance kits for free public use: mobile phones were distributed around the capital city with a toll free number 117 . These call-ins were tabulated by the Ebola Surveillance Unit of the Ministry of Health every night and these constituted the data inputs for predicted Ebola trajectories issued from Geneva. This was recounted by Hans Rosling, a Swedish graphic artist and populariser of statistical data, who had been recruited by the WHO as a Deputy Director of the Ebola Emergency Response responsible for public relations. By October 16, 2014, just prior to the United States army troop deployment to Liberia, the WHO predicted publicly that by the end of 2014, the number of new Ebola cases might reach 5,000 to 10,000 per week. The CDC released through Associated Press and Reuters that by mid-January 2015 there would be almost 1.4 million cases of Ebola through West Africa. When such projections later proved absurd, these errors were never accounted for nor retracted. For the affected populations, of course, the consequences of failing to offset erroneous hyperbolic predictions are devastating. And without a comprehensive picture there is really no way to assess the main causes of death in Guinea, Liberia or Sierra Leone over 2014-2015, nor the extent to which Ebola posed the global threat that populations in G-8 countries were made to fear.

\section{Marginalizing local medical authority}

It is natural to assume that the dysfunctional test paradigms and substandard data collection methods we have observed persisting over these last three and a half decades in war torn and impoverished countries of Africa must be due to local incapacities and severely inadequate infrastructure. The glaring shortcomings of the international Ebola Emergency response to their conditions have been attributed to the absence of legal mechanisms in Africa to ensure transparency, information sharing and accountability. Local health authorities are blamed for a "lack of disclosure 
and compliance with International Health Regulations (IHR) binding for all member countries of United Nations" [87].

Assuming compliance and rule of law are so critical to reaching global health security through internationally coordinated responses to epidemics in Africa, it is hard to understand why it is that global institutions dismiss regulations and cut corners in countries where legal statutes and political will for their enforcement do exist. A glaring incident occurred in Ghana beginning in May 2015, well after the regional Ebola crisis was declared by the WHO to be over. Because Ghana was already fitted with three renowned centers for malaria trials and the population was Ebola-free, its bid was accepted to take part in the Phase II of an Ebola vaccine trial, run by GlaxoSmithKline (GSK) and the US National Institutes of Health $(\mathrm{NIH})$, backed by the WHO. The trial commenced without the informed consent of participants, and without receiving the statutory required approval of Ghana's Food and Drug Authority [88], [89]. A heated public outcry ensued [90], and an esteemed independent scientific committee was established to pursue concerns based on previous evidence of problems with the chimpanzee adenovirus type 3 (ChAd3) methodology [91], [92]. Subsequently GSK and NIH withdrew their trial program from Ghana-not because they had violated legal obligations to local health authorities, denied research subjects' right to informed consent, or ignored basic codes of medical conduct [93] but because in the interim they had gathered the requisite 30,000 samples to complete their Phase II Trials in other West African countries.

This incident of blatant disregard in the global arena for local scientific expertise, professional protocol, and rule of law in Africa is not an isolated case. The Deputy Minister of Health in Liberia disclosed early in October 2014 to the BBC World Service reporting from Monrovia that the highest echelons in their Ministry had neither requested intervention nor received prior knowledge of the purpose or medical capacities of three thousand US military personnel deployed to Liberia in October 2014 by directive of the US President [85]. Violent force was authorized throughout 2014 to quell both public and professional resistance to the invasive search and seizure activities under the aegis of the UN coordinated Ebola crisis response in Liberia, which was overseen not by medically trained practitioners but by non-medical military personnel from China, the US Army, and the UK Royal Air Force.

Yet it was stated explicitly by WHO throughout the rescue mission that the efforts to contain the Ebola outbreaks in West Africa were "hampered by cumbersome, slow, complex and costly diagnostic tests" [94]. Lest there be any doubt about the qualifications and accountability of the international agents to whom this information was available, consider this list of international agencies that partnered in the Ebola rescue mission, represented at a high profile emergency meeting called by WHO and convened on December 12, 2014, precisely because of the problem of inadequacy of the Ebola diagnostic tools in use at the time: Médecins Sans Frontières (MSF) Executive Director of their Access Campaign, as well as the Director and Epidemiologist
Clinical Biologist of the Epicenter MSF in Paris, the MSF Diagnostics Advisor based in Geneva, both the Leader and the Laboratory Advisor of the MSF Diagnostic Network based in Amsterdam, the Chief Scientific Officer, the CEO, and the Chairman of the global Board of the Foundation for Innovative New Diagnostics (FIND), the Medical Director of Fondation Mérieux, the Public Health Focal Point representative of the World Bank, a representative of the US Naval Medical Research Center, the Senior Program Officer of Diagnostics of the Bill and Melinda Gates Foundation, the Senior Health Advisor of the Swiss Agency for Development and Cooperation in Bern, US Federal Drug Administration (FDA), the Head of Blood and Tissue Pathogens, the Director of Critical Reagents Program and Medical Countermeasure Systems of the US Department of Defense, Adventitious Agents and Diagnostics in the Division of Virology of the UK National Institute for Biological Standards and Control (NIBSC), the Director of the Office of Genomics and Advanced Technologies of the Division of Microbiology and Infectious Diseases of the US National Institutes of Health $(\mathrm{NIH}) /$ National Institutes of Allergies and Infectious Diseases (NIAID)/Department of Health and Human Services (DHHS) in Bethesda Maryland, the US Center for Devices and Radiological Health $(\mathrm{CDRH})$, the Chief of the Diagnostic Systems Division of the US Army Medical Research Institute for Infectious Diseases (AMRIID), the Team Leader of Molecular and Immunodiagnostics of the National Center for Emerging and Zoonotic Infectious Diseases of the US Centers for Disease Control and Prevention (CDC), the Senior Advisor for Global Affairs of Institute Pasteur in Paris, the Senior Health Specialist of UNICEF, and the Head of Diagnostics and Therapeutics of the Public Health Agency of Canada, all met with the WHO Assistant Director-General of Health Systems and Innovation, the WHO Assistant Director-General of Polio and Emergencies, the WHO's Team Leader of the Laboratory Strengthening and Biorisk Management, representatives of the WHO Department of Essential Medicines and Health Products and of the WHO Global Malaria Program, the Program Manager of the WHO Regional Office for Europe in Copenhagen, the WHO Director of Collaborating Centre for Viral Hemorrhagic Fevers within the US Centers for Disease Control and Prevention (CDC), the WHO's Senior Manager with technical expertise in Diagnostics, among other representatives of epidemiological agencies in Cote d'Ivoire, Guinea, Liberia, Senegal [94]. In light of such a cavalry of high profile expertise, the pervasively arbitrary statistics, the haphazard data collection and inadequate means of diagnosis which were tolerated throughout the 2014 global response to 'Ebola' in West Africa is remarkable.

Since then the vigorous effort continues, to find a prophylaxis against future Ebola outbreaks. In 2016 one published study claimed to have established $100 \%$ efficacy of an rVSV-vectored Ebola vaccine [95]. But a careful review of the research design, in particular the randomization methods, reportage and qualitative analysis of adverse events, revealed it to be substandard on several fundamental counts [96]. 
The various factors impacting upon immunity in Africa are not fully understood, but one thing is clear: variety is the norm rather than the exception in the pathogenicity associated with West African Ebola, as well as AIDS, even when the sub-chromosomal dimension is the only one considered. Both host and viral factors will determine whether there will be a cause for infection or not. Thus it is a commonplace that only laboratories and repositories with maximal capabilities can maintain the viral isolates and serum from recent and local survivors to develop maximally effective vaccines in the shortest possible time. Yet before, during, and since the declared Ebola outbreak, a P5 grade laboratory infrastructure has yet to be established in the Economic Community of West African States (ECOWAS). This is not for lack of world class immunologists stationed in the region. Nonetheless the most advanced facility is a P3 grade laboratory maintained at Ghana's Noguchi Memorial Institute for Medical Research (NMIMR) where experts routinely perform viral isolations, produce antigens for ELISA testing and for immuno-fluorescent assays in lab diagnosis of some infections including HIV. But for the most bio-hazardous materials, a P3 lab is suitable only for packing and sending samples away for further research and vaccine manufacture overseas. Funding is needed in the institutes where the viral field is richest in its evolving diversity, so that the necessary cutting-edge infrastructure is in place where it is needed most, not where it can reap the most capital profit [94].

One of the professional injustices of the political economy of HIV/AIDS research lies in its deflecting overseas the advance of high profile experimental genetic engineering and vaccine research, at the expense of research pursued in the very countries where intervention is currently needed most. Biodiversity and herbal preparations in local environments from which populations are already benefiting require experimentally based regulation to monitor dosage, efficacy and safety. As is typical throughout Sub Saharan African countries, in Ghana at least sixty-one percent of the population relies exclusively on indigenous plant medicines whenever they are ill [98]. It is obvious that local benefits would derive from developing widely available indigenous resources into affordable medications that are certified and regulated as safe and effective [98].

Pharmaceutical companies require health and safety trials in-country. Otherwise counterproductive antiretrovirals are introduced to a population where they may actually exacerbate by inducing greater virulence through drug-induced mutations of the very pathogen they were designed to suppress, as well as harbouring unknown fatal side effects [99-101]. But suppose the American pharmaceutical industry were to carry out research agendas in Africa set by locally situated experts. Or short of that, suppose they conducted their clinical trials in the populations for whom their re-purposed drugs are ostensibly defined as "essential" [102]. This would integrate foreign researchers and other personnel deeply into the product development process. It would run the risk of ultimately disqualifying such products from exclusive patentability by the American companies, according to the World Trade Organization's (WTO) intellectual property rights agreements since the Uruguay Round (section 5, article 27 exemption 3 a and b) and also the WTO Dispute Settlement Understanding (article 24) of special procedures for its least-developed country members [103]. The same threat to multi-national pharmaceutical profits is risked by researching and developing indigenous products already in use in African populations. So instead, ninety percent of the funding for epidemiological and immunological research is controlled and spent on research done outside Africa [98], [104].

No one disputes that the progressive breakdown of the immune system is dependent upon a combination of factors including inadequate and contaminated water supply, septic living conditions and food insecurity leading to crossgenerational chronic under-nutrition. So some of the critics of the vaccine approach for chronic illness in Africa, including immunologists, public health experts, molecular biologists, virologists, pathologists and neonatists, regard the solution to AIDS to be abstinence from all anti-retroviral drugs, combined with adequate nutrition and treatment of AIDS-related diseases (cholera and chronic dysentery, leprosy, malaria, parasitic worms, tuberculosis, cervical cancer, lashmaniasis, herpes, pneumonia, diabetes, meningitis, typhoid) with known drugs.

But to suggest anti-retrovirals are unnecessary is tantamount to destroying one's career in African medical research [73]. For instance, when such advice was administered by South Africa's Minister of Health Manfo TshabalalaMsimang, it generated a groundswell of outrage which peaked on June 7, 2005 just prior to South Africa's Second National HIV/AIDS conference in Durban. Anti-establishment political activists of the Treatment Action Campaign demanded her resignation for being thus 'irresponsible'.

Yet it is neither irresponsible nor controversial to note that the ongoing scientific debate about HIV/AIDS remains inconclusive because the phenomena that the debate addresses are not uniform worldwide-yet the well-funded approach to eradication of viruses is uniform worldwide. Even according to the orthodox models as the cause of AIDS, HIV has an escalating number of sub-typed variant strains that are regionally divergent. The way the virus behaves in one population is measurably different from its efficiency when infecting another. After infection, there is no uniformity in what HIV in all its variants will do; neither is it clear whether nor when, if ever, it will eventuate in AIDS. As is known generally about DNA and especially of RNA, many conspiring environmental factors interact with genotypes to yield the phenotype changes of an organism and this RNA virus is no exception [26].

The diversity of HIV strains is especially pertinent concerning treatment. An anti-retroviral that appears to get excellent results in one region does not have the same beneficial effect in another and so will be counterproductive where the mix of viral characteristics and host factors yield a different phenotypic result [24], [25]. This is why a major 
obstacle to developing an adequate response to AIDS in Africa is international efforts like the AIDS Vaccine Advocacy Coalition (AVAC) [105]. These global coalitions continue to interpret the feasibility and relevance of specific research proposals, programmes and treatment approaches at a distance from the malnourished and underserved populations who are purportedly the major beneficiaries of such research. At a distance, the HIV/AIDS phenomenon in all its evolving variety cannot be adequately monitored, let alone treated. This is because the epidemiological data is derived from test kits that continue to be designed using information culled through global data bases. The drugs developed as a result are unable to keep pace with the divergent factors affecting pathogenesis differently in distinct parts of Africa. So although HIV prevalence rates are claimed to have decreased, the neglected tropical diseases renamed 'opportunistic infections' are on the increase [58].

\section{Conclusion}

The considerations collated here suggest that gross errors persist in the One-Virus-Fits-All model of addressing poverty-related illness in Africa, re-categorized under umbrella labels such as 'HIV/AIDS' and 'West African Ebola'. The study of infectious disease at the genomic level is gradually turning away from surveillance of HIV variation and prevalence; and the discovery of new Ebola strains is not a high priority. But the data of chronic illness in Africa continues to have this protean nature. Microbiologists and immunologists in African research institutes require funding to monitor and analyse their own local data, and to pursue their chosen treatment options. The point of decentralising and diversifying research policy is that the pursuit of global health security for all cannot proceed successfully otherwise.

On the contrary, centralised management of data analysis and increased control of African populations [106], [107] via 'global health' initiatives continues to be rationalised in part by waiving basic standards of quality research, and by developing products that promise the widest distribution potential and profit margins possible at any given time [108]. But this is a dangerous road to travel. In the coming generation, major public health threats to coastal populations on every continent are expected to arise not from bio-terrorist attacks but from escalating percentages of unemployment, a widening gap between rich and poor [109], and mass migrations to coastal cities by refugees of flood, drought, and desertification [110]. None of these concerns can be addressed with the tunnel vision approach to problem solving typified by current applications of global funding for bacterial and viral genetics research. Whether or not you are of the growing scientific community that views virology as a science dealing with epiphenomena, one fact remains clear: the diverse regional factors influencing pathogenesis in Africa are too idiosyncratic to capture with the crude diagnostic methods employed and substandard documentation of illness in current supply.

\section{References}

1. The Netherlands Code of Conduct for Good Scientific Practice. Association of Universities of the Netherlands. 2012.

2. Evans AE. Causation and disease: Effect of technology on postulates of causation. Yale J Biol Med. 1991; 64: 513-28.

3. Papadopulos-Eleopulos E. AIDS in Africa: Distinguishing fact and fiction. World J Microbiol Biotechnol. 1995; 11: 135-43.

4. Lauritsen J. The AIDS War. New York: Pagan Press; 1993.

5. Shenton J. Positively False: Exposing the myths around HIV and AIDS. 1st ed. London: I.B. Tauris; New York: St. Martin's Press; 1998.

6. Lang S. The Gallo Case.The Case of HIV and AIDS. In: Challenges. New York: Springer-Verlag; 1998; 361-714.

7. Cochrane M. When AIDS began: San Francisco and the making of an epidemic. London: Routledge; 2004.

8. Mhiri C, Bélec L, Di Costanzo B, Georges A, Gherardi R. The slim disease in African patients with AIDS. Trans R Soc Trop Med Hyg. 1991; 86(3): 303-6. doi: 10.1016/0035-9203(92)90323-5

9. Geshekter CL. Outbreak? AIDS, Africa, and the medicalization of poverty. Transition: Harvard University International Review Journal. 1995; 67(5.3): 4-14.

10. Chirimuuta R. AIDS, Africa and Racism. London: Free Association Books; 1989.

11. Konotey-Ahulu F. What is AIDS? Watford, UK: Tetteh-A'Demeno Co; 1989.

12. Papdopulos-Eleopulos E, Turner V. Oxidative Stress, HIV and AIDS. Res Immunol. 1992; 145-48.

13. Stillwaggon E. AIDS and the Ecology of Poverty. New York: Oxford University Press; 2006.

14. Sempala $S$. Evaluation of the WHO clinical case definition for AIDS in Uganda. JAMA. 1988; 260: 3286-89.

15. Judah T. Uganda: The secret war. The New York Review of Books. 2004; 60(14): 62-64.

16. Nugent P. Africa since independence. New York: Palgrave Macmillan; 2004.

17. Tripp ML. Women and Politics in Uganda. Oxford: James Currey Publishers; 2000.

18. Britwum A, Jonah K, Tay FD. Structural Adjustment Participatory Review Initiative (SAPRI) Ghana country report.Prepared for the Tripartite National Steering Committee. Accra, August 25, 2001.

19. Geshekter CL. A critical reappraisal of African AIDS research and Western sexual stereo types. In: Lauer H. (ed.) History and philosophy of science for African undergraduates. Ibadan: Nigeria: Hope Publications. 2003; 75109.

20. Maniotis A, Geshekter CL. Global health strategies to fight AIDS in Africa require reliable evidence not emotional excess. In: Lauer $\mathrm{H}$, Anyidoho $\mathrm{K}$. Reclaiming the Human Sciences and Humanities through African Perspectives. Accra: Sub Saharan Publishers. 2012; 587-610.

21. WHO. Workshop on AIDS in Central Africa. Bangui, CAR. Oct. 22-25, 1985. Document WHO/CDS/AIDS/85.1, Geneva.

22. WHO. Acquired Immunodeficiency Syndrome (AIDS) WHO/CDC case definition for AIDS. Weekly Epidemiological Record. 1986; 61: 69-76.

23. Fiala C. Dirty tricks over AIDS figures. New Africa. 1998: 36-38.

24. Brandful JAM, Apeagyei FA, Ampofo WK, et al. The Relationship Between Immuno clinical Status and Prevalence of Viral Sexually Transmitted Diseases Among HIV-1 Seropositive Patients in Ghana. Viral Immunol. 1999; 12(2): 131-37.

25. Brandful JAM, Ampofo WK, Apeagyei FA, Bediako KA, Osei MK. Predominance of HIV type-1 among AIDS and AIDS Related Complex Patients in Ghana, West Africa. EastAfr Med J. 1997; 74: 17-20. 
26. Brandful JAM. Lauer H. A simplified view of human immunodeficiency virus and its manifestation in Ghana. In: HIVM 612: Course Reader for Master's Degree in Ethical Issues in HIV Management. Accra: University of Ghana Institute of Continuing and Distance Education; 2012: 116-129. http://reference.rethinkers.net/ethical_issues/HIVM612-EthicallssuesInHI VandAIDSManagement.pdf Accessed November 5, 2017.

27. Goodson P. Questioning the HIV-AIDS hypothesis: 30 years of dissent. Frontiers in Public Health. 2014; 2(154). doi: 10.3389/fpubh.2014.00154

28. Bauer HH. 'The Origins, Persistence and Failings of HIV/AIDS Theory'. Jefferson, NC: McFarland; 2007.

29. Johnson KM, Lange JV, Webb PA, Murphy FA. Isolation and partial characterization of a new virus causing acute haemorrhagic fever in Zaire. Lancet. 1977; 12: 569-71. doi: 10.1016/S0140-6736(77)92000-1

30. Pattyn S, Jacob W, Van der Growen G, Piot P, Courteille G. Isolation of Marburg-like Virus from a Case of Haemorrhagic Fever in Zaire. Lancet. 1977; 12: 573-74. doi: 10.1016/S0140-6736(77)92002-5

31. Bowen ETW, Lloyd G, Harris WJ, Platt GS, et al. Viral haemorrhagic fever in Southern Sudan and Northern Zaire. Lancet. 1977; 12: 571-72.

32. Rasnick D. David Rasnick investigates Ebola: Interview with David Crowe. The Infectious Myth. 2014; 19. November 6, 2017. AlsoCrowe D, Ely E. Interview with David Rasnick. How Positive Are You. podcast episode no. 89, November 25, 2015.

33. Ellis DS, Stamford S, Lloyd G et al. Ebola and Marburg Viruses: I. some ultra structural differences between strains when grown in Vero cells. $J$ Med Virol. 1979; 4: 201-11. doi: 10.1002/jmv. 1890040306

34. Leroy EM, Gonzalez JP, Baize S. Ebola and Marburg hemorrhagic fever viruses: major scientific advances, but a relatively minor public health threat for Africa. ClinMicrobiol Infect. 2011; 17: 964-76. doi: 10.1111/j.1469-0691.2011.03535.x

35. McCormick JB, Webb PA, Krebs JW, Johnson KM, Smith ES. A prospective study of the epidemiology and ecology of Lassa fever. $J$ Infect Dis. 1987; 135(3): 437-44

36. Gonzalez JP, Josse R, Johnson ED, et al. Antibody prevalence against haemorrhagic fever viruses in randomized representative Central African populations. Res Virol. 1989; 140: 319-31. doi: 10.1016/S0923-2516(89)80112-8

37. Gonzalez JP, Nakoune E, Slenczka W, Vidal P, Morvan JM. Ebola and Marburg virus antibody prevalence in selected populations of the Central African Republic. Microb Infect. 2000; 2: 39-44. doi: 10.1016/ S1286-4579(00)00287-2

38. Johnson ED, Gonzalez JP, Georges A. Haemorrhagic fever virus activity in equatorial Africa: distribution and prevalence of filovirus reactive antibody in the Central African Republic. Trans $R$ Soc Trop Med Hyg. 1993; 87: 530-35. doi: 10.1016/0035-9203(93)90075-2

39. Becquart $P$, Wauquier $N$, Mahlakolov $T$, et al. High prevalence of both humoral and cellular immunity to Zaire ebolavirus among rural populations in Gabon. PLOS ONE. 2010; 9. doi: 10.1371/journal. pone.0009126

40. Wauquier N, Becquart P, Padilla C, Baize S, Leroy EM. Human fatal Zaire Ebola virus infection is associated with an aberrant innate immunity and with massive lymphocyte apoptosis. PLoSNegl Trop Dis. 2010; 4(10): 837. doi: 10.1371/journal.pntd.0000837

41. de Harven E. Human Endogenous Retroviruses and AIDS research: Confusion, consensus, or science? JPANDS. 2010; 15(3): 69-74, http:// www.jpands.org/jpands1503.htm. Accessed July 10, 2017.

42. Rodríguez B, Sethi, AK, Cheruvu VK, et al. Predictive value of plasma HIV RNA level on rate of CD4 T-cell decline in untreated HIV infection. JAMA. 2006; 296: 1498-1506. doi: 10.1001/jama.296.12.1498

43. Weiss SH, Cowan EP. Laboratory detection of human retroviral infection. In: Wormser GP AIDS and Other Manifestations of HIV Infection. Cambridge, Mass: Elsevier, 2004.

44. Johnston $\mathrm{R}$, Irwin $\mathrm{M}$, Crowe D. A rebuttal to the NIAID/NIH document 'The evidence that HIV causes AIDS'. 7, 2017. https://www.scribd.com/ document/38702101/Johnston-NIH-Rebuttal-March2003 Accessed Nov. 7, 2017.
45. Duesberg PH, Koehnlein C, Rasnick D. The chemical bases of the various AIDS epidemics: recreational drugs, anti-viral chemotherapy and malnutrition. Z Naturforsch[C]. 2003; 28: 383-412.

46. Blanchard A, Montagnier L. AIDS-associated mycoplasmas. Annu Rev Microbiol. 1994; 48: 687-712. doi: 10.1146/annurev.mi.48.100194.003351

47. Papadopulos-Eleopulos E, Turner VF, Papadimitriou JM. Has Gallo proven the role of HIV in AIDS?. Emergency Medicine. 1993; 5: 113-23. doi: 10.1111/j.1442-2026.1993.tb00414.x

48. Layne SP, Merges MJ, Dembo M, et al. Factors underlying spontaneous inactivation and susceptibility to neutralization of human immunodeficiency virus. Virology. 1992; 189: 695-714. doi: 10.1016/0042-6822(92)90593-E

49. Duesberg PH. Human immune deficiency virus and acquired immune deficiency syndrome: correlation but not causation. ProcNatlAcadSci USA. 1989; 86: 755-64.

50. Schieffelin JS, Shaffer JG, Goba A, et al. Clinical Illness and Outcomes in Patients with Ebola in Sierra Leone. N Engl J Med. 2014; 29. doi: 10.1056/ NEJMoa1411680

51. EU European Centre for Disease Control and Prevention. Ebola virus disease case definition for reporting in EU. https://ecdc.europa.eu/en/ ebola-virus-disease-case-definition-reporting-eu. Accessed Nov. 72017.

52. World Bank. The Economic Impact of the 2014 Ebola Epidemic: Shortand Medieum-Term Estimates for West Africa. Washington DC: World Bank; 2014. doi: 10.1596/978-1-4648-0438-0

53. Mateusz MP, Guilavogui T, Sidikiba S, Daikité $N$, et al. Effect of the Ebolavirus-disease epidemic on malaria case management in Guinea, 2014: a cross-sectional survey of health facilities. Lancet Infect Dis. 2015. doi: 10.1016/S1473-3099(15)00061-4

54. United Nations General Assembly. Universal Declaration of Human Rights. Article 25.1. UN 217(III) A; Paris: United Nations. 1948. http://www.unorg/ed/universal-declaration-human-rights/. Accessed Nov. 72017.

55. United Nations General Assembly. International Covenant on Economic Social and Cultural Rights.Article 12.2.d. United Nations, Treaty series. 1976; 993(1-14531993): 8. http://www.refworld.org/docid/3ae6b36c0. html. Accessed Nov. 8, 2017.

56. Richards R. On HIV Testing.Responses to Dr. Peter J. Flegg and Tony Floyd Letters to the Editor, BMJ. 2001; <http://bmj.com/cgi/ eletters/326/7381/126/e\#30151> Accessed Nov. 8, 2017 at http://www. pharmharm.com/Testing.html

57. Richards R. Why the HIV Tests Can't Tell You Whether You Have HIV. Zenger's News Magazine. Reprinted June 7, 2002.

58. UNAIDS. 2020 HIV Prevention Road Map - Accelerating HIV prevention to reduce new infections by $75 \%$. United Nations political declaration on ending AIDS: 2020 Global Prevention Targets and Commitments. October 17, 2017.

59. Centre for Diseases Control and Prevention. Perspectives in Disease Prevention and Health Promotion Public Health Service Guidelines for Counseling and Antibody Testing to Prevent HIV Infection and AIDS MMWR. 1987; 36(31): 509-15.

60. Cleary PD, Barry MJ, Mayer KH, et al. Compulsory premarital screening for the human immunodeficiency virus: Technical and public health considerations. JAMA. 1987; 258: 1757-62. doi: 10.1001/jama.1987.03400130071036

61. Papadopulos-Eleopulos E, Turner VF, Papadimitriou JM. Has Gallo proven the role of HIV in AIDS? Emergency Medicine. 1993; 5: 113-123. doi: 10.1111/j.1442-2026.1993.tb00414.x

62. Layne SP, Merges MJ, Dembo $M$, et al. Factors underlying spontaneous inactivation and susceptibility to neutralization of human immunodeficiency virus. Virology. 1992; 189: 695-714. doi: 10.1016/0042-6822(92)90593-E

63. Hässig A, Kremer H, Lanka S, Liang W-X, Stampfli K. 15 Years of AIDS. Continuum. 1998; 5(3): 32-37.

64. Padian NS, Shiboski SC, Glass SO, Vittinghoff E. Heterosexual transmission of human immune deficiency virus (HIV) in Northern California: results from a ten-year study. Am J Epidemiol. 1997; 146: 350-57. 
65. Gisselquist D, Rothenberg R, Potterat J, Drucker E. HIV infections in subSaharan Africa not explained by sexual or vertical transmission. Int STD AIDS. 2002; 13: 657-66. doi: 10.1258/095646202760326390

66. Ruggiero M, Galletti MP, Pacini S, Punzi T, Morucci G, Gulisano M. On the risk of contracting AIDS at the dissection table. Ital J AnatEmbryol. 2009; 114(2-3): 97-108.

67. Van Voorhis BJ, Anderson DJ, Martinez A, Mayer K. Detection of Human Immunodeficiency Type I Virus in Semen from Seropositive Men Using Culture and Polymerase Chain Reaction Deoxyribonucleic Acid Amplification Techniques. FertilSteril. 1991; 56(3): 588-95.

68. Konotey-Ahulu FID. AIDS in Africa: Misinformation and Disinformation. Lancet. 1987; 2(8552): 206-07. doi: 10.1016/S0140-6736(87)90777-X

69. Crowe D. A survey of legal cases: criminal treatment of people living with HIV diagnosis in Canada. Section 1, Unit 10: Ethical Scrutiny of criminal and civil laws in the era of AIDS. In: Lauer H. HIVM 612: Ethical issues in HIV and AIDS management. Accra: University of Ghana Institute of Continuing and Distance Education. 2012; 334-43.

70. Kashala O, Marlink R, llunga M, et al. Infection with HIV-1 and Human T Cell Lymphotropic Viruses among Leprosy Patients and Contacts. J Infect Dis. 1994; 169: 296-304.

71. Konotey-Ahulu FID. HIV antibody positive sub-Saharan African patients in UK. Lancet. 1990; 335: 46-47.

72. Okot-Nwang M. Interviewed by Joan Shenton. AIDS and Africa, Documentary, Dispatches Channel 4, UK, 1993, programme transcript. London: Immunity Resource Foundation; 1993; 11(10).

73. Malan R. Africa Isn't Dying of AIDS. The Spectator (London) December 2003.

74. World Health Organization. Multi-drug resistant tuberculosis. March 2017. http://www.who.int/tb/areas-of-work/drug-resistant-tb/en/ Accessed November 9, 2107.

75. Castro KG, Ward JW, Slutsker L, et al. 1993 Revised Classification System for HIV Infection and Expanded Surveillance Case Definition for AIDS Among Adolescents and Adults. MMWR. 1992; 41(17). doi: 10.1093/ clinids/17.4.802

76. Hodgkinson N. Cry, beloved country: How Africa became the victim of a non-existent epidemic of HIV/AIDS. In: Duesberg PH. AIDS: Virus- or Drug- Induced?. 1996; 347-58. doi: 10.1007/978-94-009-1651-7_27

77. Johnson C. Why the 'AIDS test' doesn't work in Africa. In: H. Lauer. History and Philosophy of Science for African Undergraduates. Ibadan, Nigeria: Hope Publications. 2003; 110-13.

78. UNAIDS.AIDS epidemic update 2001. Geneva: UNAIDS/WHO. December, 2001. UNAIDS/01.74E - WHO/CDS/CSR/NCS/2001.2.

79. Delfraissy JF. Director of Agence Nationale de Recherchesur le Sidaet les Hépatites Virales. UNAIDS. Update: A call to fast-track access to antiretroviral therapy. http://www.unaids.org/en/resources/presscentre/ featurestories/2015/october/20151005_IAPAC. Accessed Nov. 9, 2017.

80. United Nations Department of Economic and Social Affairs. World population projected to reach 9.8 billion in 2050, and 11.2 billion in 2100. New York: UN. June 21, 2017

81. USAID/Bureau for Africa (1995). A Strategic Framework for Setting Priorities for Research, Analysis, and Information Dissemination on HIV/ AIDS, STIs, and Tuberculosis in Africa. Washington: USAID, 1995.

82. UNAID. Uganda Epidemiological fact sheet on HIV/AIDS and sexually transmitted infections - 2000 update. Geneva: WHO. http://data.unaids. org/publications/fact-sheets01/uganda_en.pdf. Accessed Nov. 8, 2017.

83. Duesberg PH, Mandrioli D, McCormack A, et al. AIDS since 1984: No evidence for a new, viral epidemic - not even in Africa. Ital J AnatEmbriol. 2011; 116(2): 73-92.

84. World Health Organization, UNAIDS, UNICEF. Epidemiological fact sheet on HIV and AIDS; core data on epidemiology and response, South Africa. Geneva: WHO. 2008: 1-19.

85. British Broadcasting Corporation. Worldservice News Daily, broadcasts October 5, 16, 24, 2014, December 1, 2014 and March 23, 2015.
86. American Academy of Arts and Sciences. New study finds malaria typhoid - not Ebola - biggest health threat for travelers to tropics. Am J Trop Med Hyg. Released January 16, 2013. Eurekalert, the global source for science news. http://www.eurekalert.org/pub_releases/2013-01/bcnsf011413.php Accessed Nov. 8, 2017.

87. Rull M, Kickbusch I, Lauer H. Policy Debate | International Responses to Global Epidemics: Ebola and Beyond. International Development Policy Revue internationale de politique de développement. 2016. doi: 10.4000/ poldev. 2178

88. Ghana Academy of Arts and Sciences. Press statement: On Proposed Phase II Clinical Trial of a Vaccine for Ebola Virus Disease in Ghana. Issued by the Honorary Secretary, GAAS, \#1 CSIR Close, Liberation Link, Accra. June 12, 2015.

89. Kummervold PE, Schulz WS, Smout E, Fernandez-Luque L, Larson HJ. Controversial Ebola vaccine trials in Ghana: a thematic analysis of critiques and rebuttals in digital news. BMC Public Health. 2017; 17-642. doi: 10.1186/s12889-017-4618-8

90. Ghana News. Doubts over integrity of Ebola Trials. Ghana News, July 5 2015. www.ghanaweb.com/ GhanaHomePage/NewsArchive/Doubtsover-integrity-of-Ebola-trials-366573. Accessed on 11 April 2016.

91. Quershi H G, Meritxell L, Fritts MB, McChesney, M. Robert-Guroff and C.J. Miller. Infection with host-range mutant adenovirus 5 suppresses innate immunity and induces systemic CD4+ T cell activation in Rhesus Macaques. PLOS ONE. 2014; 9(9): 106004. doi: 10.1371/journal.pone. 0106004

92. Thaci $B$, Ulasov EA, Wainwright MS, Lesniak. The challenge for gene therapy: innate immune response to adenoviruses. Oncotarget. 2011; 2(3): 113-21. doi: 10.18632/oncotarget.231

93. American Medical Association Code of Medical Ethics. Patient Rights and Responsibilities.Adopted by AMA in 2001. In: Pozgar, GD. Legal and Ethical Issues for Health Professionals. Sudbury Massachusetts: Jones and Bartlett Publishers, 2005: 270-71, 340-47.

94. World Health Organization. Urgently needed: rapid, sensitive, safe \& simple Ebola diagnostic tests, Summary Report of the Joint WHO/FIND meeting on Diagnostics and Ebola Control, Geneva. December, 12, 2014. http://www.who.int/medicines/ebola-treatment/ meetings/2015-0123 EbolaDxMtg_reportDec2014_Final.pdf. Accessed April 11, 2016.

95. Henao-Restrepo AM, Camacho A, Longini IM et al. Efficacy and effectiveness of an rVSV-vectored vaccine in preventing Ebola virus disease: final results from the Guinea ring vaccination, open-label, cluster-randomized trial (Ebola ÇaSuffit!). Lancet. 2016; 22. doi: 10.1016/ S0140-6736(16)32621-6. Accessed July 10, 2017.

96. Crowe DR. "Ebola ÇaSuffit!" is not enough to prove efficacy of an Ebola vaccine. Am J Immunol. 2017; 13(3): 165-172. doi: 10.3844/ ajisp.2017.165.172. http://thescipub.com/abstract/10.3844/ofsp.11329 Accessed August 20, 2017

97. Papadopulos-Eleopulos E, Turner VF, Papadimitrious JM, Causer D, Alphonso H, Miller T. A critical analysis of the pharmacology of AZT and its use in AIDS. Cur Med Res Opin. 1999; 15(1): 1-45. doi: 10.1185/03007999909114096. Accessed Nov. 8, 2017.

98. Akosa $A B$. Thinking forward, moving forward: planning the future of Ghana's health care delivery. In: Lauer H. HIVM 612: Ethical Issues in HIV and AIDS Management, Course Reader 2013; 365-407.

99. Center for Diseases Control and Prevention. Serious Adverse Events Attributed to Nevirapine Regimens for Post-exposure Prophylaxis After HIV Exposures. MMWR. 2001; 49-51: 1153-56.

100. Piliero PJ, Purdy B. Nevirapine-induced Hepatitis: A case series and review of the literature. AIDS Read. 2001; 11(7): 379-82.

101. Sidley P. News: HIV drug under review as firm withdraws FDA application. BMJ. 2002; 324: 807.

102. Velasquez $\mathrm{G}$. The right to health and medicines: the case of recent multilateral negotiations on public health, innovation and intellectual property. Dev World Bioeth. 2014; 14(2): 67-74. doi: 10.1111/dewb.12049

103. World Trade Organisation. The Legal Texts: The Results of the Uruguay Round of Multilateral Trade Negotiations. NY: Cambridge University Press; 1999: 133-73. 
104. Schüklenk U, Ashcroft R. Affordable access to essential medicines in developing countries: conflicts between ethical and economic imperatives. J Med Philos. 2002; 27(2): 179-95. doi: 10.1076/jmep.27.2.179.2989

105. AIDS Vaccine Advocacy Coalition. http://www.avac.org Accessed November 11, 2017.

106. Elbe S. Security and Global Health: toward the medicalization of insecurity. Cambridge: Polity Press; 2010.

107. Elbe S. Bodies as battlefields: the medicalization of insecurity. International Political Sociology. 2012; 6(3): 320-22. doi: 10.1111/j.1749-5687.2012.00166-3.x
108. Shah A. Pharmaceutical corporations and medical research. May 12, 2000. http://www.globalissues.org/article/52/pharmaceutical-corporations-andmedical-research. Accessed March 15, 2015.

109. Nicoletti G. Organization for Economic Cooperation and Development (OECD) Structure Policy Analysis Division. Interviewed on Business Daily. BBC World Service. 2014. http://downloads.bbc.co.uk/podcasts/ worldservice/bizdaily/bizdaily_20140806-1108b.mp3. Accessed August $10,2014$.

110. Kilcullen D. Out of the Mountains. $2^{\text {nd }}$ ed. New York: Oxford University Press; 2015. 